\title{
STRATEGIC MANAGEMENT OBJECT AS AN OBJECT OF SCIENTIFIC RESEARCH
}

\author{
Mykola BONDAR', \\ Kyiv National Economic University named after Vadym Hetman, Ukraine \\ Natalia IERSHOVA ${ }^{2}$, \\ National Technical University "Kharkiv Polytechnic Institute", Ukraine
}

\begin{abstract}
The purpose of research is to highlight the main areas of the system of strategic management accounting, improvement of the principles on which it operates. Subject of research is theoretical and practical aspects of functioning and development of strategic management accounting. Subject area is focused on strategic management information support towards the implementation of the principle of balancing of activity of the entities. Objectives of the research is to determine the place and role of strategic management accounting in the creation of information infrastructure management in the current economic conditions; disclosure of decomposition problems and improvement of the functioning of the system of strategic management accounting, prioritization of development. Hypothesis of the research is based on the assumption that the effectiveness of entities management adapted to the needs of the market environment of complete, accurate and timely information, which is formed in properly organized system of strategic management accounting. Methodology is based on analysis of data of respondents from 125 industrial entities of Kharkiv region. Data was collected through direct surveys and in the preparation of Kharkiv Oblast Development Strategy for the period until 2020. Respondents were asked a number of questions that determine: results of the system of information support of strategic management in enterprises employing respondents; direction of the system of strategic management accounting in enterprises employing respondents. By means of expert assessments was evaluated important source of information for making strategic management decisions. General system of research methodology is based on a systematic approach. Conclusion. During the research was confirmed the role and importance of strategic management accounting information for the purpose of strategic management. According to the results outlined challenges facing the leaders of Ukrainian enterprises based on the survey to improve performance. Advanced the system of principles that ensures the efficiency of strategic management accounting technologies as information support of strategic management. Practical implications. Distributions of identifying key areas of the system of strategic management accounting in industry, innovation-active enterprises of the Kharkiv region proves that, if necessary, this generation information system for strategic management must take into account the interests of several groups of users. System of principles of strategic management of accounting as an information technology management provides strategic improve of its practical use and determine development priorities. Value/originality. Coverage of the main directions of the system of strategic management accounting on the basis of survey of respondents and their opinions and studies of their thoughts had the aim to determine the prospects of development of the system as a whole, and industrial, innovation-active enterprises of Kharkiv region in particular.
\end{abstract}

Key words: strategic management accounting, strategic directions of implementation of management accounting, principles of the strategic management accounting, strategic management phases.

JEL Classification: M41, C13

\section{Introduction}

Increased aggressive competitive environment requires rethinking the management of all management functions, including accounting, to provide new features to management accounting, analysis and control planning. One of the strategic management accounting management accounting is focused on strategic decision making (Shevchuk, 2011; Nikolaeva \& Alekseeva, 2008; Manyaeva, 2010). Main objectives and tasks of strategic management accounting are directly derived from the objectives and tasks of strategic management.

\footnotetext{
Corresponding author

${ }^{1}$ Department of Accounting of Business Activities, Kyiv National Economic University named after Vadym Hetman.

E-mail: nibondar@mail.ru

${ }^{2}$ Department of Economic Analysis and Accounting, National Technical University "Kharkiv Polytechnic Institute".

E-mail: natalia_iershova@mail.ru
} 
Dialectic relationship of strategic management accounting and management problems is seen in outline with information of the last (Shevchuk, 2011, Golov, 2006). Main focus in determining the strategic management accounting is its external orientation (Kaplan, 1984; Summons, 1982; Bromwich, 1990). "Strategic management accounting is a means of providing information necessary to support strategic decisions in organizations" (Kaplan, 1984, p. 414). At the same time, strategic management accounting is considered in the light of information provision and monitoring development strategy (Summons, 1982). No doubt that the strategic management of the company based on inside information relationship with the environment, i.e. on the principle of consistency. Thus, for long-term operation and development of the company organization and functioning of strategic management accounting can be decisive. However, analysis of scientific papers reveals that the lack of science-based methodology of strategic management accounting as the accounting and analytical systems management. Strategic management accounting system still did not become an integral part of business and management practices, which is one of the causes of low efficiency of business entities.

Purpose of the research and research tasks. Purpose of the research is to highlight the main areas of the system of strategic management accounting, improvement of the principles on which it operates. Scientific research task: to determine the place and role of strategic management accounting in the creation of information infrastructure management in the current economic conditions; decomposition reveal problems and to improve the functioning principles of strategic management accounting and prioritize its development.

Hypothesis of the research. Hypothesis of the research is based on the assumption that the effectiveness entities of strategic management adapted to the needs of the market environment of complete, accurate and timely information, which is formed in properly organized system of strategic management accounting.

Methodology and design of the research. Overall research methodology is based on a systematic approach. Kharkiv region development strategy for the period up to 2020 includes specific initiative for businesses that are aimed at strengthening the strategic position, information support of strategic management decisions, better managing cash. Thus, data was collected through direct survey of 125 respondents from industrial enterprises that implement innovations of the 168 specified in the Statistical Yearbook of the Kharkiv region (48\% of the total as of 01.01.2015 year) (Statistical Yearbook "Kharkiv region in 2014", 2014). Method of expert evaluations (Vasilieva \& Lialin, 2012) identified the importance of certain sources of information when making management decisions on strategic set of companies selected in the framework of the research.

Design of the research involves determining the role and importance of strategic management accounting for the management of modern enterprises through the survey. Highlighting the main activities for the strategic management accounting. Determining the importance of certain areas of the strategic management accounting positions of the two groups of respondents by survey. Improvement of the functioning of strategic management accounting entities, decomposition problems and determine the prospects of development.

\section{Role of strategic management accounting}

Analysis of the literature confirms the existence of various scientific and methodological approaches in the development and implementation of strategies (Ansoff, 1979; David A. Aaker, 1984; Thompson, \& Strickland, 1997). Synthesizing existing methodological approaches allowed to highlight three main stages of strategic management: strategic planning; implementation of the strategy; assessment and control of the strategy.

Strategic planning provides performance of strategic analysis. Role of strategic management accounting information support of strategic analysis. For this purpose not only used retrospective data and the current state of the enterprise, but also the prospects for its development. Information platform in this case there is evidence of market research, analysis, business environment and external environment to identify external threats and risks; promoting harmonization of interests of the whole enterprise as a legal entity and individual employees as individuals to minimize internal threats. Implementation of the strategy involves analysis of the organizational changes that contribute to the preparation of the company to introduce new administrative decisions. Role of strategic management accounting - information support strategy implementation, including: marketing solutions (acquisition of resources, access to new markets), organizational solutions (ability to organizational changes, compensation of employees, managers), innovative solutions (development of new products, introduction of innovative management techniques) and others. Evaluation and control strategies provide steady feedback between the implementation of the strategy and goals of the enterprise. Role of strategic management accounting information support for monitoring the implementation of decisions.

Thus, strategic management accounting information can be used as an information platform to support the implementation of each step of the process of strategic management.

In order to obtain results for the practical use of strategic management accounting as information support of strategic management research conducted at the enterprises of the Kharkiv region (Statistical Yearbook "Kharkiv region in 2014," 2014). Research was conducted on 125 industrial enterprises of Kharkiv region that implement innovations ( $48 \%$ of the total as of 01.01 .2015 ). Results confirm that the majority of these companies traced the absence or lack of system functioning system of strategic management 
accounting as information support of strategic management. Thus, $81 \%$ of respondents from among managers of these companies believe that the system of strategic management accounting as information support of strategic management of their enterprises is carried out not in full, $10 \%$ - system of strategic management accounting as information support of strategic management is not carried out at all, and only $9 \%$ of respondents said that their companies functioning system of strategic management accounting as information support of strategic management (Fig. 1).

This state of the respondents explain, first of all, different interpretation of the essence of strategic management accounting, lack of theoretical development on the use of analytical accounting and strategic management accounting information system strategic management, insufficient understanding by management of strategic importance and role of management accounting. Thus, respondents in answering the question: "Do you need for your enterprise system promoted strategic management?" gave affirmative response that confirms the relevance of this area of research.

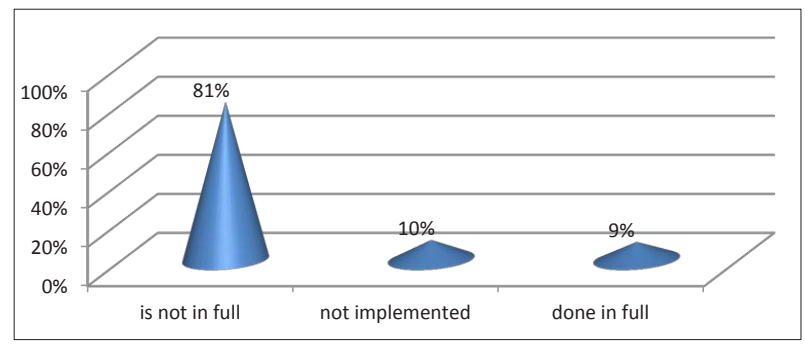

Fig. 1. Results of research on the functioning of information support of strategic management at the industrial enterprises of Kharkiv region that implement innovation
In determining the views of managers on the importance of strategic management accounting at the enterprises where they work, the answers were distributed as follows (Fig. 2).

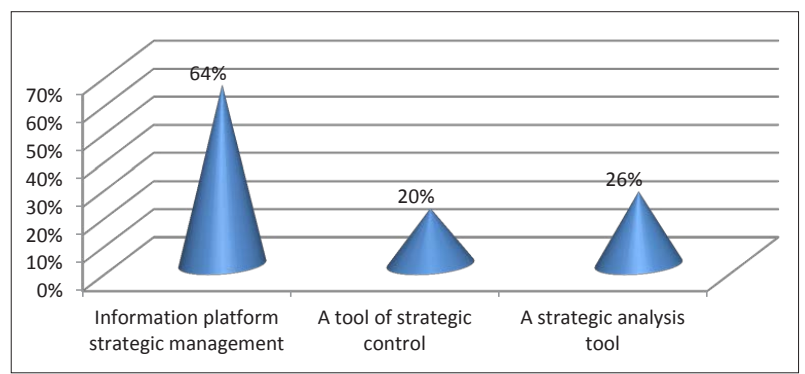

Fig. 2. Distribution of respondents' views on the importance of strategic management accounting at the enterprises where they work

Vast majority of respondents (64\%) believe that the system of strategic management accounting information platform of strategic management. Almost equally distributed respondents identifying system of strategic management accounting as a tool for strategic control (20\%), strategic analysis tool (26\%).

Thus, we can name the following types of strategic management accounting:

- Accounting activities, which includes the collection, registration management information for strategic purposes; - Analytical work, which includes identification and analysis of key indicators for the strategic direction;

- Control activities that include verification and detection of deviations from plans and rules checking and adjusting implementation of strategic plans.

Table 1

Distribution of identifying key areas of the system of strategic management accounting under groups of respondents, in \% and ranked places

\begin{tabular}{|c|c|c|c|c|c|}
\hline \multirow{3}{*}{ № } & \multirow{3}{*}{ Areas of the strategic management accounting } & \multicolumn{4}{|c|}{ Status of respondents } \\
\hline & & \multicolumn{2}{|c|}{ managers } & \multicolumn{2}{|c|}{ shareholders } \\
\hline & & in $\%$ & rank & in $\%$ & rank \\
\hline 01 & $\begin{array}{l}\text { providing strategic management of information about the business environment } \\
\text { in order to identify major trends and their potential macro impact on } \\
\text { performance and competitive position of the company }\end{array}$ & 24 & 10 & 20 & 10 \\
\hline 02 & $\begin{array}{l}\text { providing strategic information management for planning business strategy in } \\
\text { the process of decomposition }\end{array}$ & 16 & 8 & 10 & 7 \\
\hline 03 & providing strategic control & 11 & 7 & 8 & 5 \\
\hline 04 & $\begin{array}{l}\text { providing ongoing monitoring of the state of the microenvironment to study } \\
\text { trends, trends and significant changes }\end{array}$ & 22 & 9 & 18 & 8 \\
\hline 05 & providing the rational and efficient use of resources of the enterprise & 5 & 4 & 9 & 6 \\
\hline 06 & $\begin{array}{l}\text { implementation of forecasting performance effectiveness and efficiency of the } \\
\text { enterprise as a whole and in the context of the strategic business units for a } \\
\text { certain term }\end{array}$ & 7 & 6 & 5 & 4 \\
\hline 07 & $\begin{array}{l}\text { minimize risks related to false accounting information that formed in the } \\
\text { accounting system }\end{array}$ & 3 & 2 & 4 & 3 \\
\hline 08 & $\begin{array}{l}\text { information support identification of issues of strategic development of } \\
\text { enterprise }\end{array}$ & 4 & 3 & 21 & 9 \\
\hline 09 & $\begin{array}{l}\text { performing analysis of ways to reduce costs or enhance product differentiation } \\
\text { production through the use of links in the value chain and optimize cost }\end{array}$ & 6 & 5 & 3 & 2 \\
\hline 10 & other areas & 2 & 1 & 2 & 1 \\
\hline
\end{tabular}


Separation of analytical and accounting functions, one-sided vision of strategic management accounting methodology only as a set of accounting procedures outside the context of analytic functions, reduces the effectiveness of strategic management accounting and separation from the inner management.

\section{Areas of the strategic management accounting}

In support of this conclusion, we have attempted to determine the significance of individual areas of operation of strategic management accounting from the perspective of shareholders (owners of individual shareholders, expected investors) and managers (specialists who are directly related to the process of formation and strategic management decisions) industrial enterprises of Kharkiv region, implementing innovations. In this case, the respondents had to rank these areas on value for themselves on a scale of 1 to 10 , where 10 is the most significant. Results are given in Table 1. Managers (specialists that are relevant to the process of formation and strategic management decisions), see the main purpose of the strategic management accounting in the information security strategic analysis, planning and control. This ranking is justified and meets the goals and objectives that decide the managers.

From the perspective of shareholders of one of the most important areas of the strategic management accounting, too, is the identification information on issues of strategic corporate development. They see a system of strategic management accounting information platform as a strategic management tool development or management decisions concerning the operation and development of the company in a changing external and internal environment. Thus, as shareholders and experts are unanimous in their views that the system of strategic management accounting is an information platform for the management decisions of strategic nature. Summary results for the two groups of respondents are shown in Fig. 3.

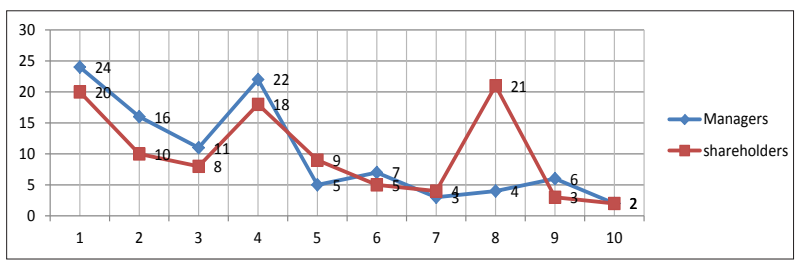

Fig. 3. Generalized distribution parameters defining the main directions of the system of strategic management accounting of groups of respondents, $\%$

In support of this conclusion, was performed research of the importance of certain sources of information for the main directions of the strategic management accounting in enterprises. On the basis of expert assessments (Grabovetsky, 2010), formed an expert group of 12 persons, which included representatives of the top management of the industrial enterprises of Kharkiv region implementing innovation among surveyed during the previous study.

They were offered a 10-point scale to rank the importance of information sources for strategic management decisions. Rank "1" determined the potential significance of the smallest source of information for making strategic management decisions. Performed grouping of reviews of information sources that are used in making strategic management decisions. Presented statistics examination conducted in two areas of information sources to make strategic management decisions: Block 1 External Data (CO): Statistical Information (3I1); Official financial statements (3I2); Information on Financial Markets (3I3); Results of market research (3I4); Legislative and regulatory materials (3I5); Other external information (3I6). Block 2 Inside Information (BI): Scheduled information (BI1); Analytical information (BI2); Information of management accounting (BI3); Accounting information (BI4); Statistical information (BI5) (Table. 2 ). In the last column of Table 2 is highlighted the most important source of information, the quality of which are most dependent information provision formation and strategic management decisions. Results indicate diagnostics that included among the expert professionals who are directly related to the process of formation and strategic management decisions in a certain way to insure the spread of peer reviews of randomness.

Assessment of consistency of expert opinion is carried out by calculating the coefficient of multiple rank correlation (coefficient of concordance - W) in the presence of bound ranks. As from (Vasiliev, 2012), at W>0,5 according to experts, there is nonrandom consistency. To block 1 $\mathrm{W}=0,809$; for unit $2 \mathrm{~W}=0,845$. Checking statistical reliability degree of consistency of expert opinion is carried out under $\chi^{2}-$ Pearson criterion (Vasilieva \& Lialin, 2012). With appropriate number of degrees of freedom and significance level $\alpha=0,005$ we have: $\chi^{2}(1)=48,54 ; \chi^{2}$ $(2)=40,56$, with confidence that the probability of $99.5 \%$ confirms the statistical significance of the resulting values of concordance and opinion on the consistency of expert opinion.

These results confirm that the data management accounting, analytical, planning information and accounting information, identified as the main domestic sources for making strategic management decisions.

Official financial statements, market research data are the main external sources when making management decisions of strategic nature. Information for strategic management includes: first, going beyond the internal environment and obtain information on the environment (markets, competitors, inventory, etc.), and secondly, the definition of relationship between the selected mission (strategy) and the methodology of calculation of formation credentials.

Way to build an effective system of strategic management accounting in general and accounting in particular lies in improving its methodologies to clarify the basic information needs and search for the best ways to meet it. 
Methodology of strategic management accounting based on the need to develop an integrated approach to the formation of information space, which includes the entire cycle management procedures, taking into account the strategic positioning of the enterprise.

In this case, decomposition of tasks of management accounting is conducted in accordance with the management environment specific entity and its needs. In this connection, we offer them to structure the following criteria: in the context of business processes: procurement, production, sales; by type of management of the entity: managing the production cycle, management of commercial transactions; the level in the organizational structure of the entity: responsibility centers, enterprise as a whole; by types of facilities that are managed, media costs, activities, cost centers.

\section{Principles of functioning of strategic management accounting}

Specificity of strategic management accounting system needs improvement principles of its functioning as an information technology management software relevant information for making strategic management decisions. These principles include the following:

4.1. Principle of accounting information according to a strategic level decision-making. Strategic management level information responsible, able to provide the fullest information needs of senior management entity in solving strategic goals and objectives. Implementation strategy of the entity represented in a set sequence of business processes is one of the main objects of strategic management accounting, control and analysis, as the very strategy of the entity. Due to the magnitude of the information base, emerging as a strategic management accounting system, prerequisite for its proper perception is decomposition data centers of responsibility and levels of government. This rational allocation of responsibility for the strategically important objects between the centers of responsibility, including individual officials is a prerequisite for the successful implementation of the strategy of the entity. System of strategic management accounting and reporting should be fully linked with the current system of governance of the entity and focused on its specificity (Pankow and Nesvetaylov, 2012). Decomposition of strategic objectives and tasks levels of government and centers of responsibility determines the format of strategic management accounting, performance reporting structure and methods of grouping and generalization. On the other hand, quality and specificity of strategic management accounting information makes appropriate requirements management structure. As part of this principle is necessary to ensure full compliance with the contents of certain forms of strategic management

Table 2

Statistical valuation of expert review of the use of the type of information sources to make strategic management decisions

\begin{tabular}{|c|c|c|c|c|c|c|c|c|c|c|c|c|c|c|c|c|}
\hline \multirow[b]{2}{*}{ 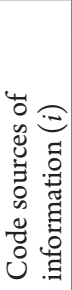 } & \multicolumn{12}{|c|}{ Expert score $\left(\right.$ managers of enterprises $\left.{ }^{*}\right)(j)$} & \multirow[b]{2}{*}{$\sum_{i=1}^{n} a_{i j}$} & \multirow[b]{2}{*}{$d_{i}=\sum_{i=0}^{n}\left(a_{i j}-\overline{a_{l}}\right)$} & \multirow[b]{2}{*}{$d_{i}^{2}$} & \multirow[b]{2}{*}{ rank } \\
\hline & 1 & 2 & 3 & 4 & 5 & 6 & 7 & 8 & 9 & 10 & 11 & 12 & & & & \\
\hline \multicolumn{17}{|c|}{ Block 1 External Information (3I) } \\
\hline $3 \mathrm{II}$ & 7 & 7 & 8 & 8 & 9 & 9 & 9 & 8 & 9 & 9 & 8 & 10 & 101 & 6 & 36 & 8,4 \\
\hline $3 \mathrm{I} 2$ & 10 & 10 & 9 & 9 & 10 & 10 & 10 & 10 & 10 & 10 & 9 & 9 & 116 & 21 & 441 & 9,7 \\
\hline $3 \mathrm{I} 3$ & 6 & 6 & 6 & 5 & 6 & 7 & 6 & 5 & 6 & 5 & 7 & 4 & 69 & -26 & 676 & 5,8 \\
\hline $3 I 4$ & 10 & 9 & 10 & 10 & 10 & 10 & 10 & 10 & 10 & 9 & 10 & 9 & 117 & 22 & 484 & 9,8 \\
\hline 3 II & 6 & 5 & 7 & 6 & 7 & 7 & 7 & 6 & 7 & 7 & 7 & 5 & 77 & -18 & 324 & 6,4 \\
\hline 316 & 8 & 8 & 7 & 7 & 8 & 8 & 8 & 7 & 8 & 8 & 6 & 7 & 90 & -5 & 25 & 7,5 \\
\hline$t^{r}$ & 2 & - & 2 & - & 2 & $2+2$ & 2 & 2 & 2 & 2 & 2 & 2 & $\bar{a}_{i}=95$ & - & $\begin{array}{l}S=\sum d_{i}^{2}= \\
=1986\end{array}$ & - \\
\hline $\mathrm{T}^{\mathrm{j}}$ & 6 & - & 6 & - & 6 & 12 & 6 & 6 & 6 & 6 & 6 & 6 & - & - & - & - \\
\hline \multicolumn{17}{|c|}{ Block 2 Inside Information (BI) } \\
\hline BI1 & 9 & 8 & 8 & 8 & 8 & 7 & 6 & 7 & 7 & 6 & 7 & 6 & 87 & -8 & 71 & 7,3 \\
\hline $\mathrm{BI} 2$ & 10 & 9 & 9 & 10 & 10 & 9 & 9 & 10 & 9 & 10 & 10 & 10 & 115 & 20 & 384 & 9,6 \\
\hline $\mathrm{BI} 3$ & 8 & 10 & 10 & 9 & 9 & 10 & 10 & 9 & 10 & 9 & 9 & 9 & 112 & 17 & 276 & 9,3 \\
\hline BI4 & 7 & 7 & 7 & 8 & 7 & 8 & 7 & 8 & 8 & 8 & 6 & 7 & 88 & -7 & 55 & 7,3 \\
\hline BI5 & 8 & 6 & 5 & 5 & 5 & 6 & 5 & 7 & 5 & 7 & 8 & 8 & 75 & -20 & 416 & 6,3 \\
\hline$t_{r}$ & 2 & - & - & 2 & - & - & - & 2 & - & - & - & - & $\bar{a}_{i}=95,4$ & - & $\begin{array}{l}\mathrm{S}=\sum d_{i}^{2}= \\
=1201\end{array}$ & - \\
\hline $\mathrm{T}_{\mathrm{i}}$ & 6 & - & - & 6 & - & - & - & 6 & - & - & - & - & & & & \\
\hline
\end{tabular}


accounting duties and information needs representatives of the Strategic Management.

4.2. Principle of flexibility in the method and tools used pursuant key strategic goals and objectives. According to this principle the choice of form and tool of strategic management accounting will be situational, allowing for the external and internal conditions, as well as specific technologies for making strategic management decisions. Each strategic management decision and possibly individually unique. As a result, the content of strategic management accounting is not static, and flexibly respond to significant changes in the macro- and micro innovations in technology production, marketing, information and management. Flexibility of the entire system of strategic management accounting, ultimately, is a prerequisite and guarantee the development and improvement of the information system management technology and, as a result, strategies of the entity.

4.3. Principle of matching strategy and organizational structure (principle of strategic units that report). This principle is similar to the accepted principle in international practice units that report (entity). Thus between them can be found significant differences. Strategic management accounting is conducted in the context of separate structural units that are organizational, economic and, above all, the strategic differences. Strategic unit that reports to a separate entity if it implements common to all its subdivisions strategy. However, in practice, the strategic reporting often formed at the respective centers of responsibility. In this case, the choice of such centers, and also for the formation of their strategic reporting strategy will be realized at the corporate level. Thus, strategic management accounting clearly implemented the principle of matching strategy and organizational structure (Chandler, 1962).

4.4. Principle of unity of space accounting and analytical decision-making. InfoBase strategic management accounting has a wide range and depends on the characteristics of strategic management and strategic goals and objectives. Process for identifying relevant strategic management focused on facts directly requests for information specialists. This single information field, on the one hand, be decentralized by centers of responsibility, on the other hand, generalization to higher levels of management. Information obtained as a result of strategic management accounting to implement specific strategies that ultimately provides a synthesized assessment of the effectiveness of implementation of basic strategies of the entity and its quality. Thus, the principle of unity of accounting and analytical space management decisions ensure full compliance with some basic strategies for key strategic installations entity. Tools of strategic management accounting is a combination of traditional methods of accounting and analysis of specific technologies and additional monitoring, identification and data collection; forecasting; analysis; decision making under uncertainty. Strategic management accounting method has limitations.
In the strategic management accounting can be used all methods and techniques relevant to the training of strategic management accounting. Principle of unity accounting and analytical space to significantly expand the range of information that is recorded; methods of accounting and analysis; implement flexible reporting strategy adapted to the characteristics of the current system of strategic management.

4.5. Principle of plurality analytical groupings expenses and accounting estimates used indicators. Closely with this principle is the requirement "different costs for different purposes." Common interpretation of the latter requirement provides its close relationship with the correspondence principle used accounting methods and procedures of key strategic goals and objectives. Their combined use makes it possible to achieve in managerial accounting necessary analytical depth and flexibility of approaches used, providing the required range of uses of the same resource costs, but grouped possible for many purposes. Thus, the strategic management accounting is possible to access multiple accounting and analytical solutions.

4.6. Equal status for the importance of quantitative and qualitative information. Extensions and complexity of management problems and complications would expand the ways and means to address them. Quantitative information can not give a complete picture, or may present a picture which violates the integrity situation. Therefore, in management accounting plays a significant role quality information, reception of which is not due to the stringent regulatory requirements or computational limitations, and delivery speed is very high.

4.7. Principle of professional judgment. Key management regulations providing high quality, relevant information suggest the implementation of the principle of judgment. Specialist who expresses the judgment, must have a sufficient level of professional knowledge, skills, have experience in this area and access to relevant information.

\section{Conclusions}

Performed studies make it possible to formulate a number of summarizing positions which expose the role and prospects of development of strategic management accounting in the management of modern enterprises.

1. System of strategic management accounting information platform serves to support the implementation of each step of the process of strategic management. Moreover, separation of analytical and accounting functions, one-sided vision of strategic management accounting methodology only as a set of accounting procedures outside the context of analytic functions, reduces the effectiveness of strategic management accounting and separation from the inner management.

2. Among the problems facing the leaders of Ukrainian enterprises a central place occupies a rethinking of all management functions, including account and to provide new features management accounting, planning, analysis and control. 
3. System of principles for the operation of strategic management accounting as an information technology management software ensure that the contents of certain forms of strategic management accounting duties and information needs representatives of Strategic management, choice of forms and tools for conducting strategic management accounting, use of multiple performance indicators.

4. Prospects for the development of strategic management accounting is the development and implementation of appropriate organizational methods and tools which allow you to generate the information necessary for strategic business development. Current system of accounting and analytical support essential needs new content as a set of interrelated and interactive methods, techniques, procedures and models designed to justify making strategic management decisions at the company. It should include all, without exception, accounting and analytical tools to obtain synergies from their complex application while ensuring a stable and sustainable financial condition.

\section{References}

Ansoff, I. (1979). Strategic Management - New York, John Wiley, 236 p.

Bromwich, M. (1990). The case for strategic management accounting: the role of accounting information for strategy in competitive markets. Accounting, Organization and Society, Vol. 1, p. 27-46.

Chandler, A.D. (1962). Strategy and Structure: Chapters in the History of the Industrial Enterprise - Cambridge, MIT Press, $463 \mathrm{p}$.

David, A. (1984). Strategic Market Management - New York, John Wiley, 322 p.

Kaplan, R.S. (1984). The Evolution of Management Accounting. The Accounting Review, Vol. 59, No. 3. (Jul., 1984), p. 390-418.

Summons, K. (1982). Strategic management accounting for pricing: a case example. Accounting and Business Research. Vol. 12 (47), p. 58-66.

Thompson, A. \& Strickland, A. (1997). Strategic Management: Concepts and Cases Published by Richard D Irwin, $450 \mathrm{p}$.

Vasilieva, E. \& Lialin, V. (2012). Statistics - Moscow, Unity, Dana, 398 p.

Grabovetsky, B. (2010). Methods of expert assessments: theory, methodology, application areas - Vinnitsa, VNTU, $171 \mathrm{p}$.

Golov, S. (2006). Management accounting - Kyiv, Libra, 351 c.

Manyaeva, V. (2010). Theoretical Fundamentals development of strategic management accounting. Vestnik of Samara State University, № 1 (63), p. 47-51.

Nikolaeva, O. \& Alekseeva, O. (2008). Strategic Management Accounting - Moscow, LKI, 304 p.

Pankov, V. \& Nesvetaylov, V. (2012). Basic principles and assumptions of the strategic management accounting. international accounting, № 7, p. 2-7.

Statistical Yearbook "Kharkiv region in 2014". Electronic resources. http://www.kh.ukrstat.gov.ua/

Strategy for the period until 2020. Kharkiv Oblast Development/ Electronic resources.

http://old.kharkivoda.gov.ua/documents/16203/1088.pdf

Shevchuk, V. (2012). Strategic management accounting information as a basis of strategic management enterprise. Vestnik of National University "Lviv Polytechnic», № 722, p. 281-285.

\section{Николай БОНДАРЬ, Наталья ЕРШОВА \\ СТРАТЕГИЧЕСКИЙ УПРАВЛЕНЧЕСКИЙ УЧЕТ КАК ОБЪЕКТ НАУЧНЫХ ИССЛЕДОВАНИЙ}

Аннотация. Предметом исследования являются теоретические и практические аспекты функционирования и развития системы стратегического управленческого учета. Предметная область ориентирована на информационное обеспечения стратегического управления в направлении реализации принципа сбалансированности деятельности субъектов хозяйствования. Цель исследования состоит в освещении основных направлений функционирования системы стратегического управленческого учета, совершенствовании системы принципов на которых она функционирует. Задача исследования состоит в определении места и роли стратегического управленческого учета в создании информационной инфраструктуры управления в современных условиях хозяйствования; раскрытие декомпозиции задач и усовершенствования системы принципов функционирования системы стратегического управленческого учета. Гипотеза исследования основывается на предположении, что эффективность управления субъектами хозяйствования требует приспособленной к рыночной среде полной, достоверной и своевременной информации, которая формируется в надлежащим образом организованной системе стратегического управленческого учета. Методология основывается на статистическом анализе данных опроса респондентов со 125 промышленных предприятий Харьковского региона. Данные были собраны с помощью непосредственного опроса в ходе подготовки Стратегии 
развития Харьковской области на период до 2020 года. Респондентам предлагалось несколько вопросов, которые определяли: результаты функционирования системы информационной поддержки стратегического управления на предприятиях, где работают респонденты; направления функционирования системы стратегического управленческого учета. С помощью метода экспертных оценок была оценена важность источников информации для принятия стратегических управленческих решений. Общая система исследование базируется на методологии системного подхода. Выводы. В ходе исследования подтверждена роль и значимость информации стратегического управленческого учета для целей стратегического управления. По полученным результатам, очерчены проблемы, стоящие перед руководителями украинских предприятий на основе проведенного опроса с целью повышения эффективности деятельности. Усовершенствована система принципов, которые обеспечивает эффективность функционирования стратегического управленческого учета как технологии информационного обеспечения стратегического управления. Практическое использование. Распределение показателей определение основных направлений функционирования системы стратегического управленческого учета на промышленных, инновационно активных предприятиях Харьковской области доказывает, что при необходимости генерирования информации данной системой для стратегического управления необходимо учитывать интересы нескольких групп пользователей. Система принципов функционирования стратегического управленческого учета как технологии информационного обеспечения стратегического управления предоставляет возможность улучшить ее практическое использование и определить приоритеты развития. Значение. Освещение основных направлений функционирования системы стратегического управленческого учета на основе результатов опроса респондентов и исследование полученных результатов имели целью определить перспективы развития данной системы в целом, и на промышленных, инновационно активных предприятиях Харьковской области в частности. 